Article

\title{
Sonic Tomograph as a Tool Supporting the Sustainable Management of Historical Greenery of the UMCS Botanical Garden in Lublin
}

\author{
Margot Dudkiewicz ${ }^{1, *(\mathbb{D} \text { and Wojciech Durlak }}{ }^{2}$ \\ 1 Department of Landscape Architecture, Faculty of Horticulture and Landscape Architecture, \\ University of Life Sciences in Lublin, Głęboka St. 28, 20-612 Lublin, Poland \\ 2 Horticultural Production Institute, Faculty of Horticulture and Landscape Architecture, \\ University of Life Sciences in Lublin, Głęboka St. 28, 20-612 Lublin, Poland; wdurlak@autograf.pl \\ * Correspondence: margotdudkiewicz@o2.pl; Tel.: +48-696900453
}

Citation: Dudkiewicz, M.; Durlak, W. Sonic Tomograph as a Tool Supporting the Sustainable Management of Historical Greenery of the UMCS Botanical Garden in Lublin. Sustainability 2021, 13, 9451. https://doi.org/10.3390/su13169451

Academic Editors: Elena Cristina Rada and Ivo Machar

Received: 25 June 2021

Accepted: 19 August 2021

Published: 23 August 2021

Publisher's Note: MDPI stays neutral with regard to jurisdictional claims in published maps and institutional affiliations.

Copyright: (c) 2021 by the authors. Licensee MDPI, Basel, Switzerland. This article is an open access article distributed under the terms and conditions of the Creative Commons Attribution (CC BY) license (https:// creativecommons.org/licenses/by/ $4.0 /)$.

\begin{abstract}
The mission of botanical gardens is to work towards the conservation and sustainable use of plant diversity. In the case of gardens established on the premises of former manor estates, actions are also being taken to properly manage existing natural resources, e.g., historic tree stands. This article is based on the case study of the Botanical Garden in Lublin. To assess the health condition of the trees growing in the oldest part of the park-Kościuszko Redoubt—sonic tomography examinations were performed. The article presents the practical application of a newer form of digital imaging, put to the service of assessing the health of old trees in an important public space. The Redoubt is the only work of defense architecture in Poland related to the activity of General Tadeusz Kościuszko, the hero of Poland and the United States of America. It has survived in an excellent condition, preserved without significant changes, as an earth structure with ramparts; an interior, i.e., a yard; a cannon post located on an inaccessible cliff; and a brick basement serving as a shelter for soldiers and a warehouse. The entire surroundings also survived: ravines masked with a wild green, embankments with a safe hidden access road to the Redoubt, and a shaped defense line. The Botanical Garden area is located in the Sławinek district, in the valley of the Czechówka River, and includes a fragment of it and the slope adjacent to the west, cut by three loess ravines. The Botanical Garden was established in 1965, where there was a manor farm earlier, and then in the 19th century, a spa that was destroyed during World War I and II. Good soils and a varied microclimate provide the right ecological conditions for the high biodiversity of plants. With an area of 21.15 ha, the Garden area has the character of a landscape park with the theme of a manor garden from the turn of the 18th/19th century and a spa garden. The primary purpose of the work was to investigate the effectiveness of the use of computer tools in the sustainable management of historical greenery in the Botanical Garden. Research has shown that diagnostics with the use of sound waves allow for an accurate diagnosis and quick protective measures against the tree, improving the safety of visitors to the botanical garden. Moreover, the obtained results and a historical query were used to prepare an application to recognize Redoubt as a monument.
\end{abstract}

Keywords: sustainable management of greenery; city; sound tomography; Picus Sonic 3; natural monument; Lublin; UMCS botanical garden

\section{Introduction}

The Botanical Garden is an institution that conducts scientific activity within the scope of its duties, protects endangered species, and cares for preserving biodiversity. Each Garden is different due to its history, habitat conditions, guiding principles, and composition. For example, the area now occupied by the UMCS Botanical Garden was a health resort, and before that, a manor park. The oldest parts of the Garden are the Kościuszko Redoubt and the linden alley leading to the manor. Considering historic 
trees, continuous, ongoing care, and keeping them in good condition while maintaining appropriate conservation standards, are particularly important factors [1-5]. Thanks to using a sonic tomograph, old specimens of trees growing here were diagnosed, and then measures were taken to protect, preserve, and inhibit the processes of their destruction. Based on the obtained research results and the conducted historical analyzes, this area was entered into the Lublin register of monuments.

Older trees are an important part of a self-sufficient natural environment (mixed aged forest), and this technology supports sustainable development. Good practice in managing a botanical garden requires taking into account the real risk posed by historical tree specimens and adequately assessing the risks. Parks with an old tree stand are a substitute for the forest in the urban landscape. Although their species composition differs from the structure of a typical forest, they fulfill many environmental functions, e.g., they are elements of ecological sequences, thanks to which it is possible to migrate organisms between biotopes and ecological niches isolated by civilization. Moreover, historical green complexes often represent the mainstream of landscape parks. A landscape park is a space built, among others, by grassy surfaces, irregular and free forms of woody vegetation, and natural water elements (ponds and streams). Sometimes, the garden spreads out into a distant landscape.

In botanic gardens, there are occasions in which individual trees can fail under the influence of high wind loads and cause inconvenience and pose a danger to people and property. A part of these parks comprises thousands of mature trees that can be found growing along roadsides, squares, or cafes. Consideration of hazard tree risks can inform broader decisions on long-term vegetation management to enable a functioning, healthy, and safe urban environment for future users of roads and recreation areas [6-9]. Care of veteran trees includes cuts to remove deadwood branches, cuts of crowns limiting their weight and volume, and the installation of bindings and elastic protections. Conservation also includes the management of natural monuments. The routine inspection in detail should be developed not only through visual assessment but also monitoring using recommended technology to assure the entire condition of the tree [10]. It is impossible to eliminate all risk associated with trees. Nonetheless, the science of tree stability analysis makes an important contribution to not only public safety but also our enjoyment of trees by providing, if not a perfect, at least an improved method to measure tree stability, thus increasing our comfort level in the urban [11-13]. The examination of trees with the use of computed tomography allows one to look inside the trunk and to assess the structural changes of the wood much better. This allows one to determine the condition of the trees more precisely and prevent their cutting down where it is unnecessary. As a result of the study, accurate information is obtained on the size and location of rot, scum, and other defects affecting the stability of the tree. The condition of the tree can be accurately assessed, which was once impossible and sometimes ended with too hasty logging. The presented research can be called innovative because it is one of the first sonic tomograph tests of trees in Lublin.

This manuscript summarizes the process by which large trees are protected in Botanical Garden in Lublin, how they gain protected status, and the use of acoustic tomography to assess the structural soundness of five trees. The authors discuss tree stresses and tree care options, and how the outcome of each assessment was used in the decision making process.

\section{Historical Outline of the Object}

At the end of the 18th century, Sławinek was a village belonging to the Firlej family, who came from nearby Dabrowica. The property was lying on the Warsaw-Lublin road, on the Czechówka River, flowing into Bystrzyca. This place was associated with the remains of a mysterious castle. There was a manor house and a small farm in Sławinek. In the second half of the 18th century, the property was owned by Jan Nepomucen Kościuszko, starost of Krzemieniec, uncle of Tadeusz Kościuszko-the initiator of the insurrection in 1794 [14]. The first arrival and stay of Tadeusz Kościuszko in Lublin lasted from 1774 to $1775[15,16]$. According to legend, Tadeusz personally planted a linden tree for his uncle. 
The tree marked the central alley leading from the main gate and the Czechówka river to the manor house. It can be assumed with a high degree of probability that the Redoubt in Sławinek was established in the spring of 1792. It can be assumed that the idea was conceived as early as 1790 when T. Kościuszko was appointed commander of the Lublin garrison and made many efforts to improve the city's defenses [17,18].

According to the Universal Encyclopedia of Orgelbrand from 1866 [19], a redoubt in the Old Polish sense is: "A field fortification, in the shape of a square or rectangle, with an embankment and moats, with a different number of cannons and the necessary crew." According to Meciszewski (1825) [20]: "a redoubt is a closed rampart, usually foursided, convex towards the enemy." The internal space of the Redoubt is a "settlement" for shooting soldiers in two rows; the first "shooter", the second "weapon loader."

The Redoubt in Sławinek was situated on an important communication route from Ruthenia, running through Lublin to Warsaw. Its task was to stop the possible march of enemy troops towards the capital. It is through the valley of the Czechówka river, through today's streets-Północna, Biernacki, Ruska, Kalinowszczyzna, and Słomiany Rynek to the bridge over the Bystrzyca river near the "Papiernia" mill—where Czechówka flows into Bystrzyca. During past wars the highest location in the area was chosen for the construction of the Redoubt, in hard-to-reach terrain, among winding ravines. There was also an additional obstacle in the form of a wide water reservoir and a significantly narrowed wet valley. The Redoubt in Sławinek did not participate in the hostilities, although it was well-prepared for them. Thus, it has survived in the quiet of a park between an old Polish manor and a farm until our times and, most importantly, without significant changes or severe damage during past wars $[17,18]$. The Redoubt in Sławinek is the only work of defense architecture in Poland related to Kościuszko's activity.

At the end of the 18th or the beginning of the 19th century, Sławinek became the property of Jan Dawid Heyzler, a Lublin banker. In 1819, Paweł Wagner became the owner of the Sławin estate. Following the example of Nałeczów, he established a suburban bathhouse on the estate for the residents of Lublin. In 1859, the Wagner brothers and their sister Julia Medrkiewicz became the new owners of Sławinek. In 1860, the small baths were turned into a bathing establishment used by the inhabitants of the Lublin Governorate and the entire Kingdom of Poland. In 1879, the health resort and the manor house became the property of Stanisław Medrkiewicz, who tried to develop a bathing facility and a park. At that time, the park and bathrooms were tidied up, and a few houses for patients and a large restaurant were built. The best years of the bathing establishment in Sławinek were at the beginning of the 1880s. At the end of the decade, however, it began to decline. In 1896, the restaurant and the dance hall burned down. The Austrian army, which took Lublin in 1915, also destroyed it. Despite the destruction, Sławinkowski Park was still decorated with old trees, lilies blooming on two ponds, and a wooden bridge over the Czechówka river. During World War II, most of the trees were cut down. The Germans took over Sławinek and built a restaurant, "Lindenhorst", in the park, which was converted into a children's camp after the war. The last owner of the Treatment Plant in Sławinek was Zofia Rudnicka née Mędrkiewicz, daughter of Jan-the owner of Sławinek in the interwar period. In 1946, Sławinek was included in the agrarian reform, and its lands were parceled out [21]. In 1950, the Maria Curie-Skłodowska University bought from Zofia Rudnicka née Mędrkiewicz a remnant with the manor, allocating the area for the planned Botanical Garden.

Currently, the area of 21.25 ha is divided into 12 divisions: Department of Tuberous and Bulbous Plants, Department of Dendrology (Arboretum), Department of South and South-Eastern European Plants, Biblical Plants, Department of Polish Flora, Department of Mountain Plants (Alpinarium), Department of Plants Ornamental Plants, Rosarium, Department of Plant Systematics, Department of Tropical and Subtropical Plants, Department of Utility Plants, and Department of Aquatic and Swamp Plants. The Garden's collections include over 1600 species of trees and shrubs, including over 3300 herbaceous plants growing in the ground and approximately 1600 species of greenhouse plants. There are also 106 trees over 100 years old in the park. Thus, the UMCS Botanical Garden is the 
largest park in Lublin with a historic tree stand and a facility that pursues scientific and didactic goals for employees and students of Lublin universities.

\section{Materials and Methods}

The primary purpose of the work was to investigate the effectiveness of the use of computer tools in the sustainable management of historical greenery in a botanical garden.

The field research consisted of a detailed dendrological inventory of the Kościuszko Redoubt and linden alley in the UMCS Botanical Garden in Lublin. The work uses quantitative and qualitative data processing methods. The numerical parameters characterizing the objects were determined-circumference $[\mathrm{m}]$, crown reach [m], and tree height $[\mathrm{m}]$. The location of selected trees was determined based on GPS positioning. The trunk's circumference was measured at the height of $130 \mathrm{~cm}$ above the ground with a tape measure with an accuracy of $1 \mathrm{~cm}$. The crown projection diameter was measured with a Leica DISTO D5 rangefinder and the height of trees with a Nikon Forestry Pro altimeter. The analysis of the estimated age of the trees was based on the Majdecki age of the trees table (1980-1986) [22]. Safety of use of Reduta is very important and requires the use of technical tools of technicians. Five trees in the worst health condition were selected for CT examinations: two small-leaved lindens, two Norway maples, and one Canadian poplar. The trees showed visible signs of weakness (deadwood, small leaves, and falling bark).

The diagnostics of the inside of tree trunks with the use of tomography, which uses sound waves for analysis, allows one to visualize the health condition of their internal structure in terms of detecting rotting, voids, or scrub without the need to perform invasive overhangs $[23,24]$. When analyzing the results obtained with the tomograph, special attention should be paid to the image's color, which determines the wood density map. In the tomogram, which is the result of the study, individual colors indicate different speeds of sound propagation inside the trunk depending on the elasticity and density of the wood.

The analysis begins with tapping the trunk with a rubber hammer in order to determine the specific sound effects, which allows one to determine the level of the measurement points. Then, at the designated height, measurement pins are placed to attach the sensors responsible for receiving sound waves. Usually, 5 to 24 measuring points are assumed to be spaced apart by certain values. The number of points placed depends on the circumference and shape of the tree trunk (Figure 1).

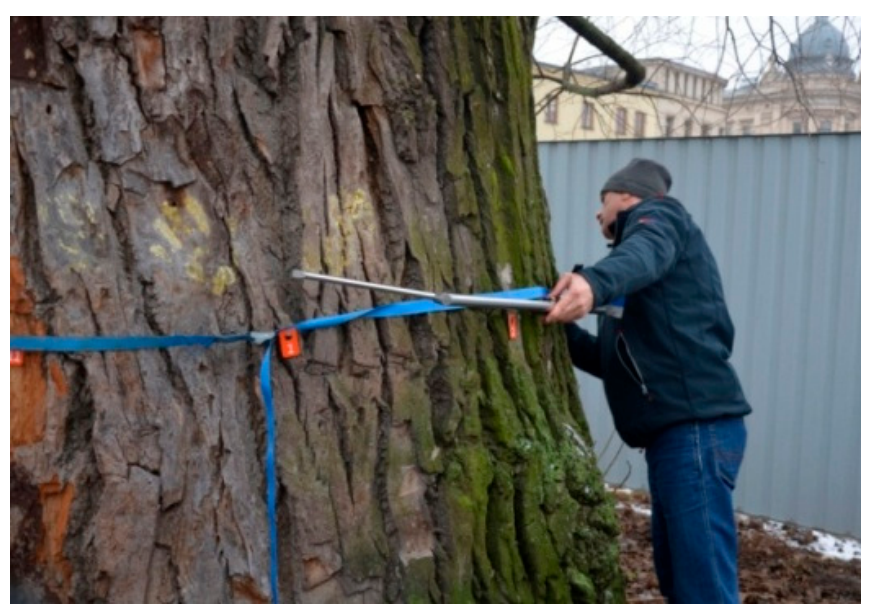

Figure 1. CT scanner sonic located on a tree trunk (W. Durlak, 2021).

The next step is to measure the tree trunk geometry, which is assessed at the measurement level. In order to accurately reproduce its shape, an electronic caliper-Picus Calliper-is used, which, after the measurement, wirelessly transmits data to the central unit of the tomograph, where it is read on the screen (Figure 2). The disadvantage of the caliper is its limited span $(\max 1.5 \mathrm{~m})$, which makes it impossible to measure trees with significant trunk circumferences. 




Figure 2. Measurement of the geometry of the tree trunk using calipers Picus Calliper (M. Dudkiewicz, 2021).

Then, a sonic measurement is made using a radio hammer. With its help, a sound pulse is generated at each subsequent measuring point, which is received by the sensors. During the generation of the wave, sensors record the time of receiving the signal. This stage is crucial, because then a visualization is created, showing the inside of the trunk (tomogram) with the exact size and location of the defect at a given height. The stage of acoustic diagnosis resembles the work of a woodpecker, hence the name. The image shown on a tomogram is usually relatively easy to interpret. The color shade from light brown to black corresponds to the speed of sound from $60 \%$ to $100 \%$, which is equivalent to a living and healthy wood tissue. Different shades of green match the speed of the sound wave from $40 \%$ to $60 \%$, which means a slight deterioration of the wood structure. Pink defines the sound range from $20 \%$ to $40 \%$, and the color shade from white to blue corresponds to the sound range from 0 to $20 \%$. The yellow lines on the cross-section of the trunk suggest the appearance of internal cracks, which are extremely dangerous because often, on the outside, there are no obvious visible symptoms that could confirm this $[25,26]$. The thicker the line, the greater the risk of this happening. On the other hand, the red line in the tomogram indicates the limit wall thickness, which allows one to determine the minimum mechanical strength of the tree trunk. Such data helps calculate the so-called $t / R$ ratio, i.e., the ratio of healthy wood ( $t$ ) to the radius of the tree trunk ( $R$ ). According to the available literature, the $t / R$ ratio should not be lower than 0.33 , and in the case of trees with closed cavities, even 0.3 [27-30]. Any values below this limit increase the risk of the tree breaking at the least expected moment.

\section{Results}

\subsection{The Existing Condition of the Redoubt}

Over the years, the earth's embankments were covered with old linden and maple trees (Figures 3 and 4). The internal slopes of the Pałacówka are an exhibition for shrubs, i.e., yews, spireas, lilacs, and flower beds in the style of a manor garden (Figure 5). In the northeast, at the corner of the embankments, there is a terrace with a view to the city, and at its foot, the Heather Hut café. The historic road to a nearby manor across the Czechówka river along the linden avenue (Figure 6). 




Figure 3. Entrance to Reduta from the westtree (photo by M.Dudkiewicz, 2021).

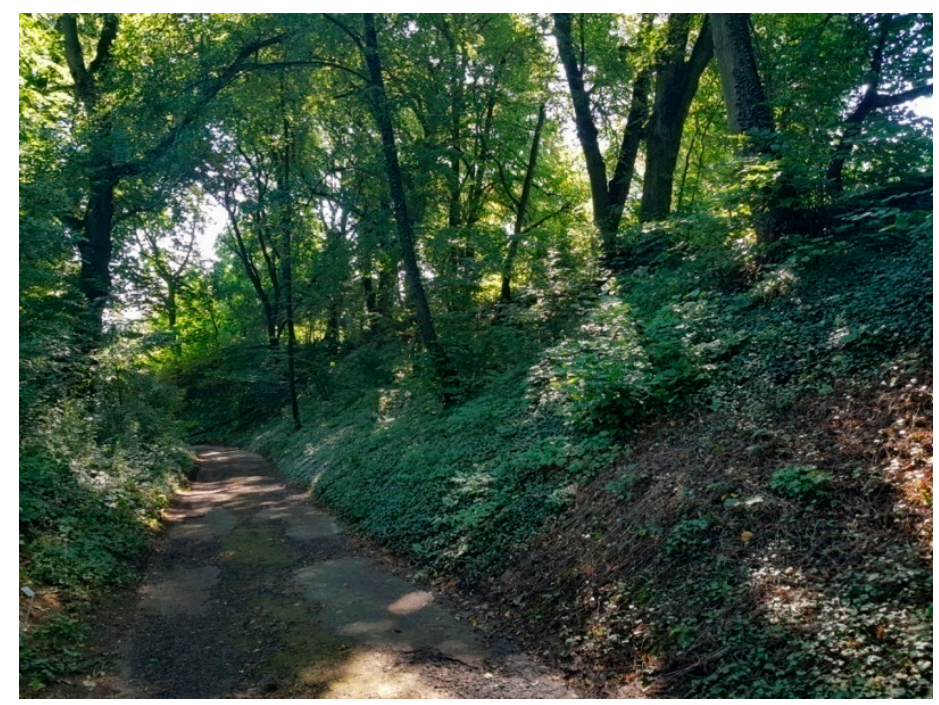

Figure 4. Northern ramparts of the Kościuszko Redoubt (photo by M.Dudkiewicz, 2021).

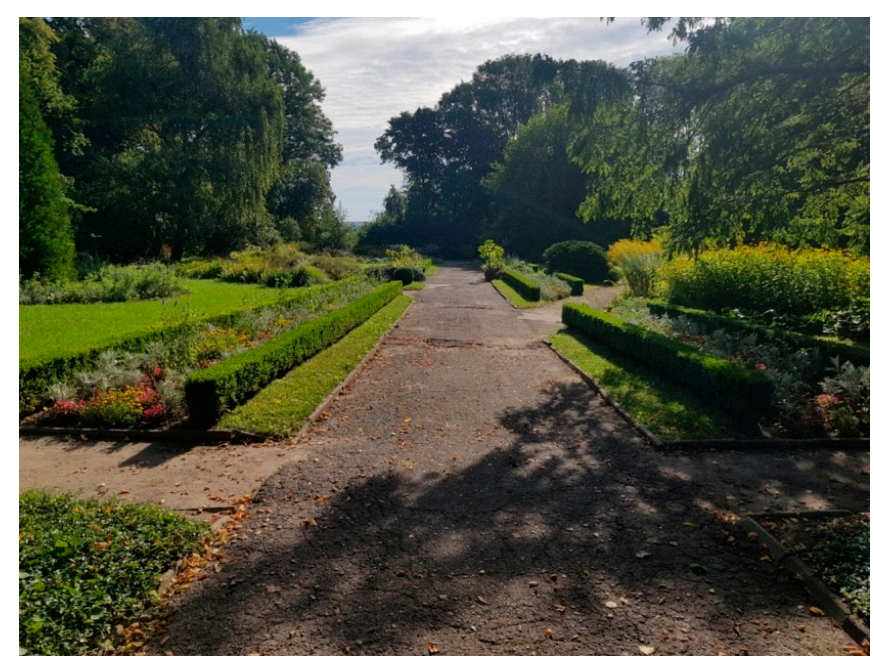

Figure 5. Decorative plantings in the former yard (courtyard of the redoubt) (photo by M.Dudkiewicz, 2021). 


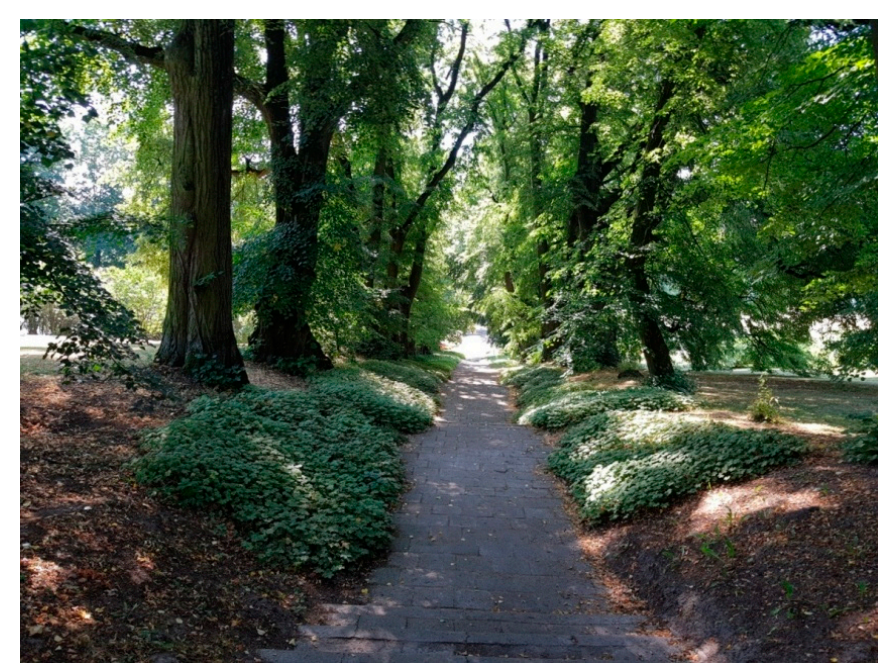

Figure 6. View of the linden avenue (photo by M.Dudkiewicz, 2021).

From the beginning of the central alley on the west side to the end of the escarpment on the east side, the fortifications measure approximately $120 \mathrm{~m}$. The width of the embankments is about $15 \mathrm{~m}$, and the width of the entire rampart is $80 \mathrm{~m}$. The embankments are about $3 \mathrm{~m}$ high, and on the eastern side, it ends a high escarpment, beneath which there is a café. The dikes were probably higher in the past, but part of the ground drained off with rainwater.

From oral records of the former employees of the Garden, we learn about the underground passageways that used to exist here, which could be accessed even in the midtwentieth century. Unfortunately, due to safety reasons, the tunnels were probably buried.

\subsection{Results of the Dendrological Inventory}

Two hundred eighty-three plants were inventoried in the Redoubt area, including trees, shrubs, groups of shrubs, and creepers. The number of trees is dominated by Norway maple (Acer platanoides L.) 28 pcs, small-leaved lime (Tilia cordata Mill.) 25 pcs, and common ash (Fraxinus excelsior L.) 6 pcs. In the alley leading to the manor house, there are 32 smallleaved lindens (Tilia cordata Mill.), nine common ash (Fraxinus excelsior L.), two common maples (Acer platanoides L.), two pedunculate oaks (Quercus robur L.), and a brittle willow (Salix fragilis L.). Five trees from the Redoubt in questionable health were subjected to specialist sonic tomography examinations (Table 1).

Table 1. Data from inventoried trees (authors).

\begin{tabular}{|c|c|c|c|c|c|c|}
\hline No. & Species Name & $\begin{array}{l}\text { The Circumference of } \\
\text { the Trunk at the } \\
\text { Height of } 1.3 \mathrm{~m} \mathrm{(cm)}\end{array}$ & Hight (m) & Crown Reach (m) & Age & Localization \\
\hline 1 & $\begin{array}{l}\text { Small-leaved lime } \\
\text { (Tilia cordata Mill.) }\end{array}$ & 264 & 15 & 9 & 116 & $\begin{array}{l}51^{\circ} 15^{\prime} 42^{\prime \prime} \mathrm{N} \\
22^{\circ} 30^{\prime} 50^{\prime \prime} \mathrm{E}\end{array}$ \\
\hline 2 & $\begin{array}{l}\text { Small-leaved lime } \\
\text { (Tilia cordata Mill.) }\end{array}$ & 313 & 16 & 6,6 & 137 & $\begin{array}{l}51^{\circ} 15^{\prime} 42^{\prime \prime} \mathrm{N} \\
22^{\circ} 30^{\prime} 50^{\prime \prime} \mathrm{E}\end{array}$ \\
\hline 3 & $\begin{array}{c}\text { Norway maple } \\
\text { (Acer platanoides L.) }\end{array}$ & 270 & 24 & 25 & 142 & $\begin{array}{l}51^{\circ} 15^{\prime} 40^{\prime \prime} \mathrm{N} \\
22^{\circ} 30^{\prime} 52^{\prime \prime} \mathrm{E}\end{array}$ \\
\hline 4 & $\begin{array}{c}\text { Norway maple } \\
\text { (Acer platanoides L.) }\end{array}$ & 230 & 24 & 13 & 121 & $\begin{array}{l}51^{\circ} 15^{\prime} 40^{\prime \prime} \mathrm{N} \\
22^{\circ} 30^{\prime} 51^{\prime \prime} \mathrm{E}\end{array}$ \\
\hline 5 & $\begin{array}{l}\text { Canadian Poplar } \\
\text { (Populus canadensis L.) }\end{array}$ & 322 & 27 & 25 & 121 & $\begin{array}{l}51^{\circ} 15^{\prime} 40^{\prime \prime} \mathrm{N} \\
22^{\circ} 30^{\prime} 49^{\prime \prime} \mathrm{E}\end{array}$ \\
\hline
\end{tabular}


Detailed metric data of trees are presented in Table 1.

\subsection{The Result of the Tomograph Examination}

\subsubsection{Object \# 1-Small-Leaved Lime Tilia cordata Mill.}

After analyzing the results of the tomographic examination, the beginnings of decomposition of the core part of the tree trunk were found (Figure 7). The destruction covers an area of approximately $650 \mathrm{~cm}^{2}(31 \mathrm{~cm} \times 21 \mathrm{~cm})$ on a cross-sectional area. This area is marked in blue and purple on the tomogram. There is also a layer of wood with a weakened structure, marked green (the so-called transition wood, with a slightly lower mechanical strength). The remaining part of the trunk's cross-section is healthy wood. After an in-depth analysis, it was shown that the technically sound (healthy) wood, in this case, occupies $76 \%$ of the trunk cross-section, which is suggested by the brown color of various shades. Damaged wood, in turn, covers $11 \%$ of the trunk cross-section, and transitional wood covers the remaining $13 \%$ of the examined area. In the attached tomogram between measuring points $9-10$ and $7-8$, thin yellow lines suggest radial cracks. However, their thickness suggests a low risk of splitting the trunk. The minimum remaining wall thickness as the safety limit against trunk fracture (red line) for this tree is, on average, $12.7 \mathrm{~cm}$. Thus, the stock of healthy wood surfaces is sufficient. Visually, the shape of the tree is satisfactory (Figure 8).

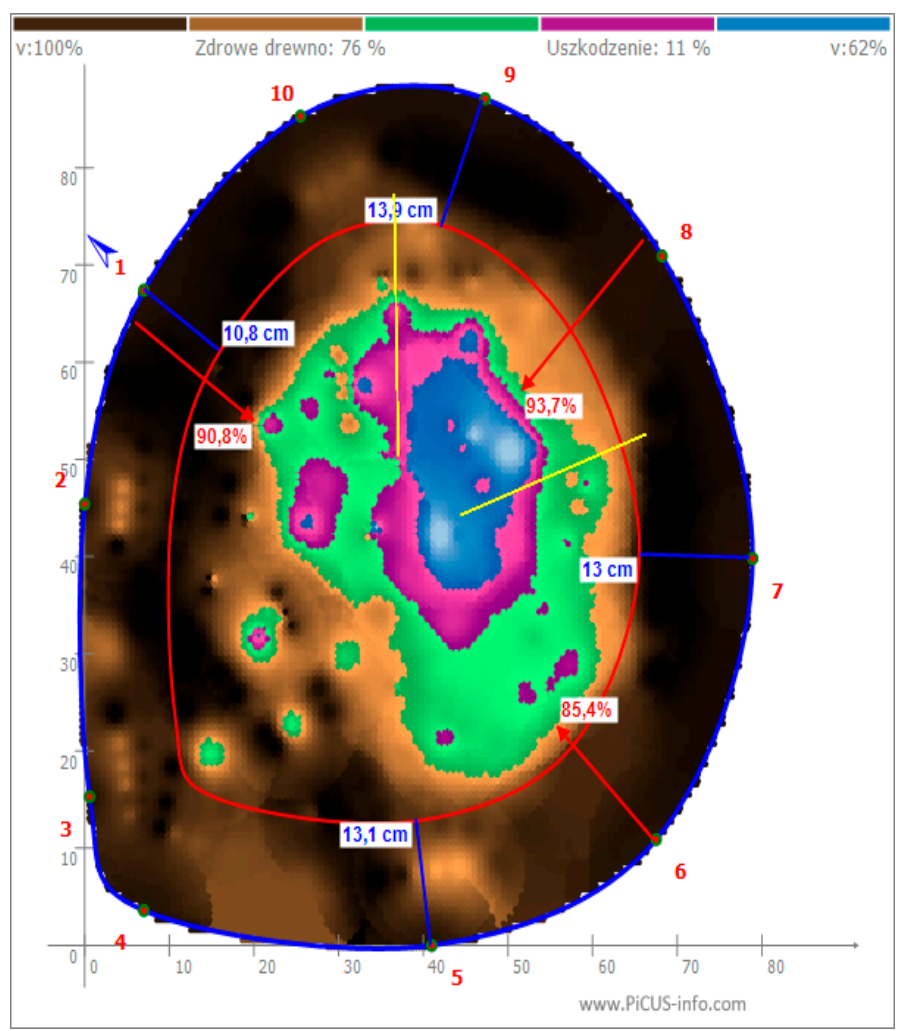

Figure 7. Tomogram of the inside of the small-leaved lime trunk inv. No. 1 (by W. Durlak).

\subsubsection{Object \# 2-Small-Leaved Lime Tilia cordata Mill.}

The processes of tissue decomposition in the examined tree are advanced and cover practically the entire cross-section of the trunk. Damaged wood constitutes $85 \%$ and healthy wood only $8 \%$ of this cross-section. The remaining area is made up of transitional wood $(7 \%)$. The geometric moment of inertia calculated for different directions for the trunk cross-section has a very low value, which indicates a high risk of trunk fracture (Figure 9). However, these calculations only consider the geometry of the trunk at the level of the measurement made. However, you still have to consider the properties of the wood itself 
(regular wood or so-called reaction wood), which may affect the final measurement result. The thick yellow lines on the tomogram also suggest a high risk of internal fractures. The minimum wall thickness (marked with a red line) considered safe should be, on average, over $16 \mathrm{~cm}$. In this case, the preserved wall does not reach even $1 / 3$ of the safe limit. The green line indicates the remaining residual wall thickness needed to prevent the tree trunk from breaking. The remaining wall has an average thickness of $4.4 \mathrm{~cm}$, but it does not appear around the entire circumference of the trunk, only on a few of its fragments. The progressive destructive processes inside the trunk resulted in irreversible changes in the wood tissues, which resulted in a poor prognosis for the tree's survival. As the tree is away from pedestrian communication routes and does not pose a significant threat to the area users, it is suggested to keep it despite significant damage to the trunk. However, for safety, a portion of the top of the crown should be removed. It will lower the center of gravity and improve the statics of the entire tree (Figure 10).

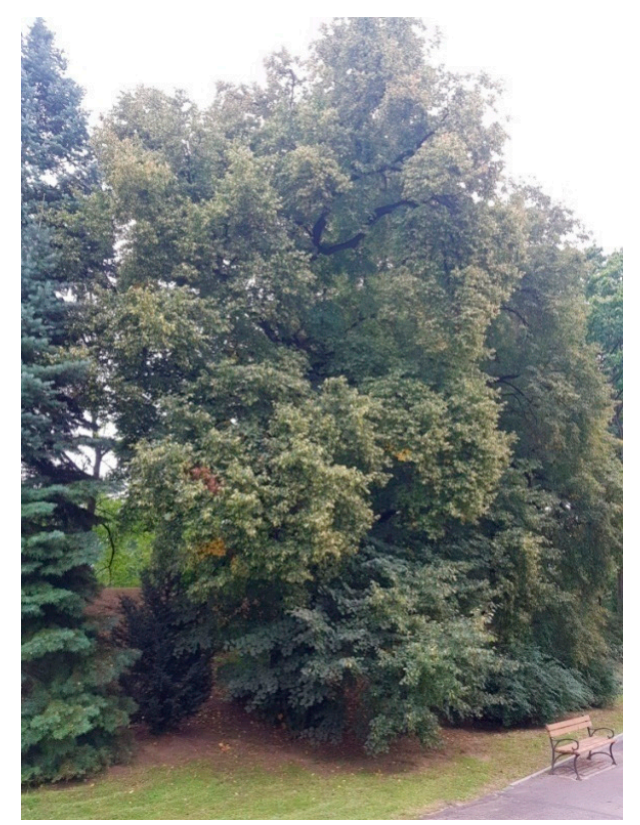

Figure 8. Small-leaved lime inv. No. 1 (photo by M. Dudkiewicz).

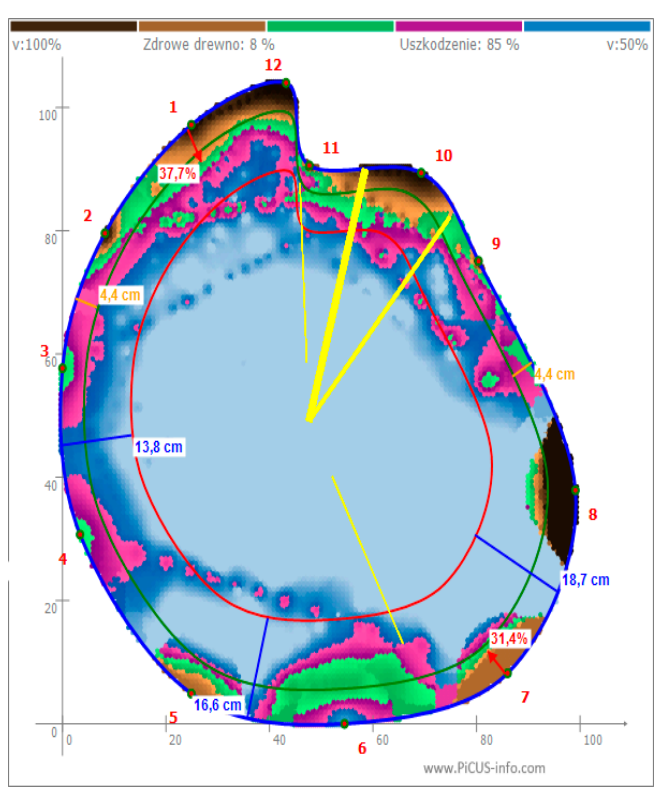

Figure 9. Tomogram of the inside of the small-leaved lime trunk inv. No. 2 (by W. Durlak). 


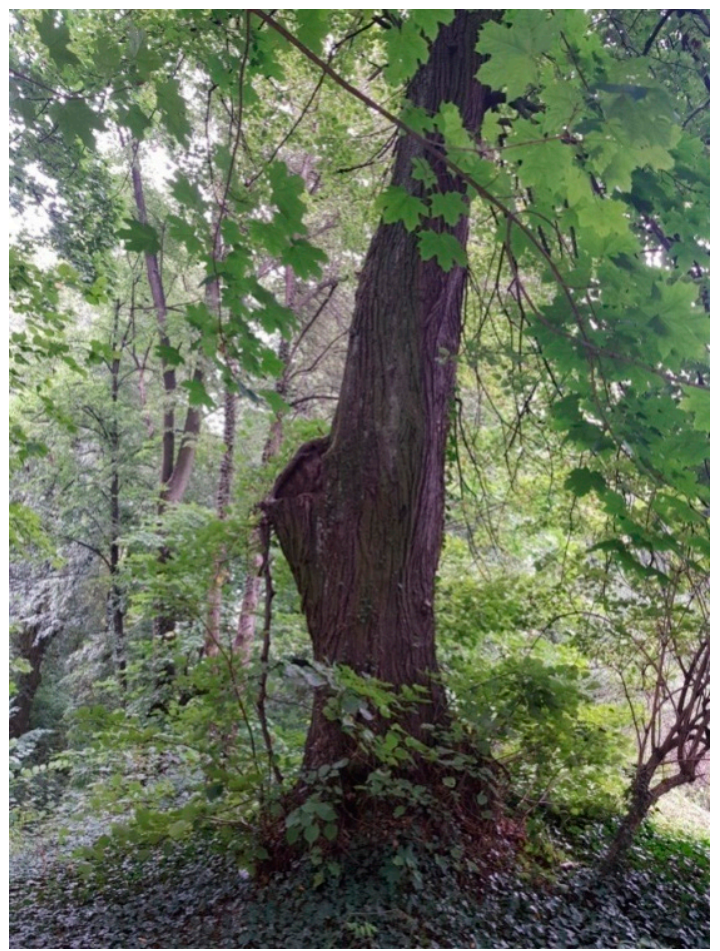

Figure 10. Small-leaved lime inv. No. 2 (photo by M. Dudkiewicz).

\subsubsection{Object \# 3-Norway Maple Acer platanoides L.}

In the examined tree, tissue destruction was found at the height of the measurement (Figure 11). Healthy wood takes $27 \%$ and damaged wood $39 \%$ of the trunk cross-section. The remaining area is transitional wood (34\%). On the north side, between points 1 and 12, there is considerable damage to the trunk's interior, measuring $45 \mathrm{~cm} \times 14 \mathrm{~cm}\left(630 \mathrm{~cm}^{2}\right)$ at the site of V-forked branches. It is also confirmed on the tomogram by a yellow line that is thicker than the others. The calculated geometric moment of inertia for the trunk cross-section of this tree ranges from 29.5\% (South-West side) to $87 \%$ (South-East side) of the maximum strength for the stem free from defects or damage. Therefore, the minimum wall thickness considered as safe should be on average $12.5 \mathrm{~cm}$. In this case, this value was recorded on the eastern side of the trunk. Estimating the minimum residual wall thickness that prevents the tree trunk from breaking and after considering all the necessary data, the required residual load capacity of the trunk (bending strength) calculated by the Tree SA method should be at least $71 \%$ (relating to the undamaged trunk), while based on tomographic measurements, the percentage of technically sound wood is much lower and amounts to only $27 \%$. Process of decomposition of tissues inside the tree trunk will certainly accelerate over the years depending on the prevailing conditions, which will result in the transformation of the transition wood into damaged wood and, as a result, deterioration of the health condition of the tree. Such a situation forces the monitoring. Visually, the shape of the tree is satisfactory (Figure 12).

\subsubsection{Object \# 4-Norway Maple Acer platanoides L.}

The examined tree showed an excellent condition of its trunk interior. The entire cross-section of the trunk at the measurement's height was characterized by $100 \%$ healthy wood (Figure 13). Only a tiny, thin, yellow line may suggest the possibility of internal cracks, but at the moment, it does not pose a significant threat to the safety of potential users of the site. Visually, the shape of the tree is satisfactory (Figure 14). 




Figure 11. Tomogram of the inside of theNorway maple trunk inv. No. 3 (by W. Durlak).

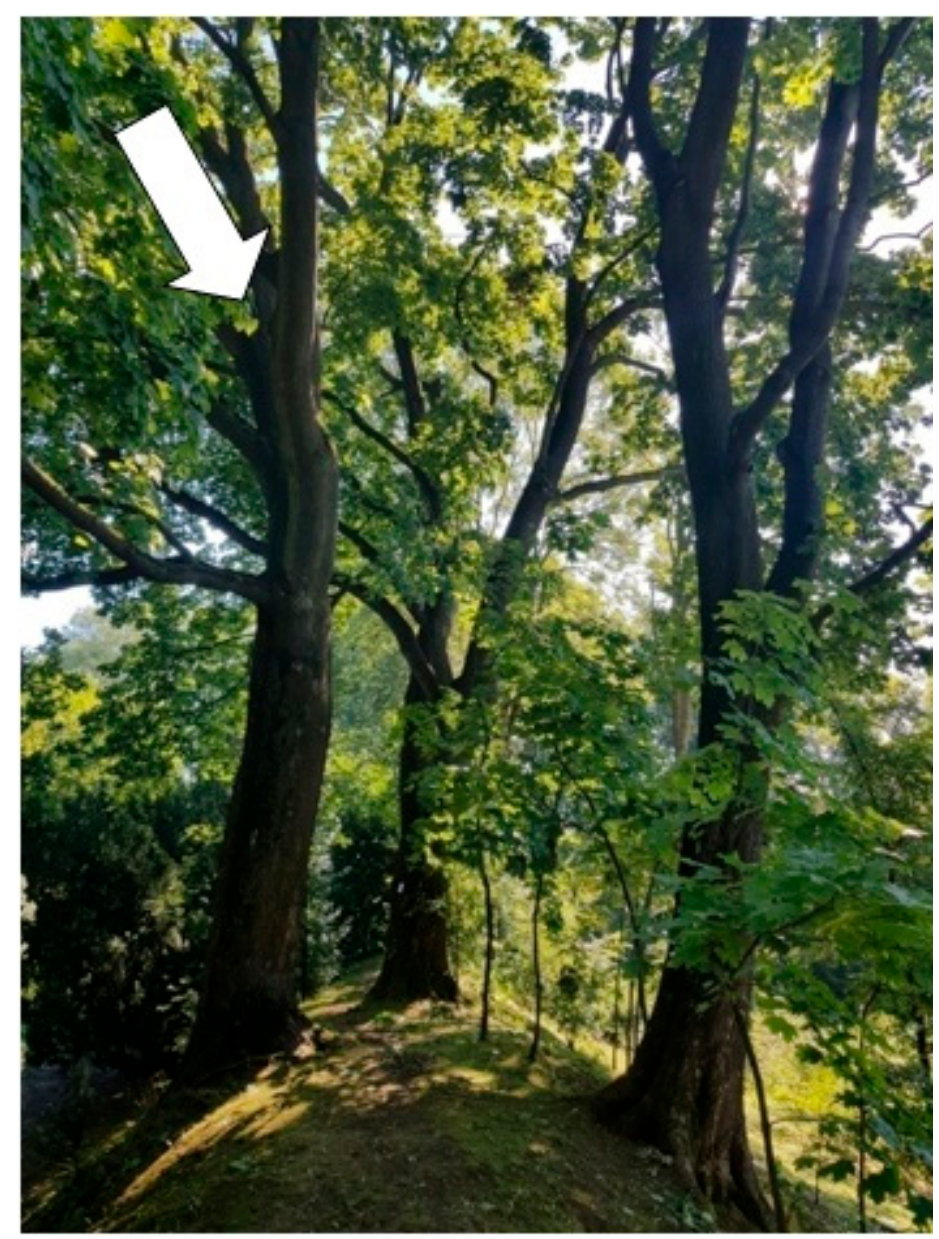

Figure 12. Norway maple inv. No. 3 (photo by M. Dudkiewicz). 




Figure 13. Tomogram of the inside of the Norwaymaple trunk inv. No. 4 (by W. Durlak).

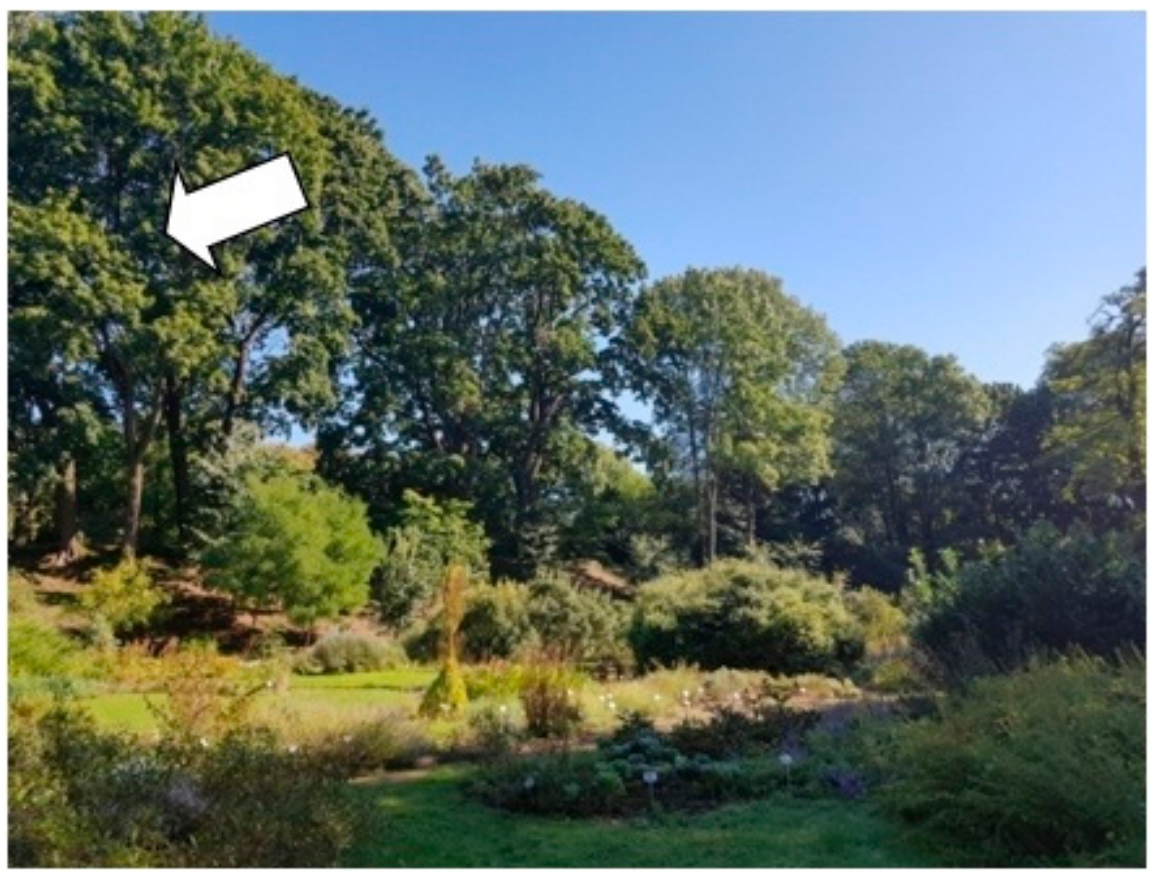

Figure 14. Norway maple inv. No. 4 (photo by M. Dudkiewicz).

3.3.5. Object \# 5-Canadian Poplar Populus canadensis L.

After analyzing the results of the tomographic examination, 99\% of the inside of the tree trunk is found to be healthy. The remaining $1 \%$ is taken up by transitional wood. However, no damaged wood is found (Figure 15). Few fragments of the trunk cross-section, including wood with a slightly weakened structure, appear only in the form of point areas located in the north, south, and south-east parts of the trunk's circumference and do not play any role in the trunk health of the tree. Visually, the tree shape is correct (Figure 16). 


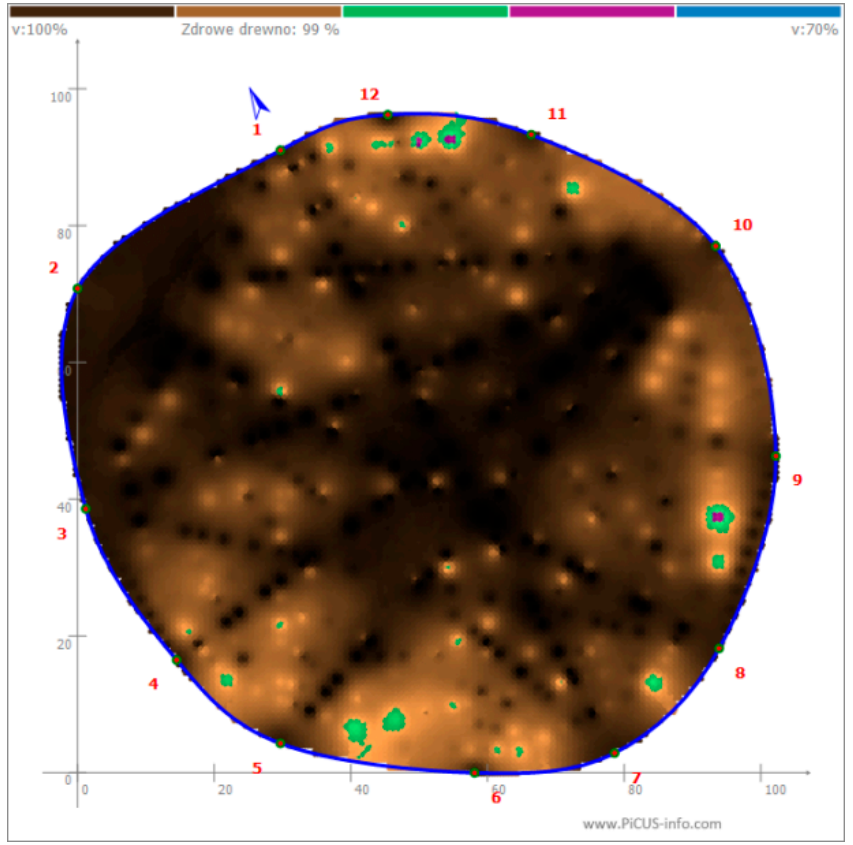

Figure 15. Tomogram of the inside of the Canadian Poplartrunk inv. No. 5 (by W. Durlak).

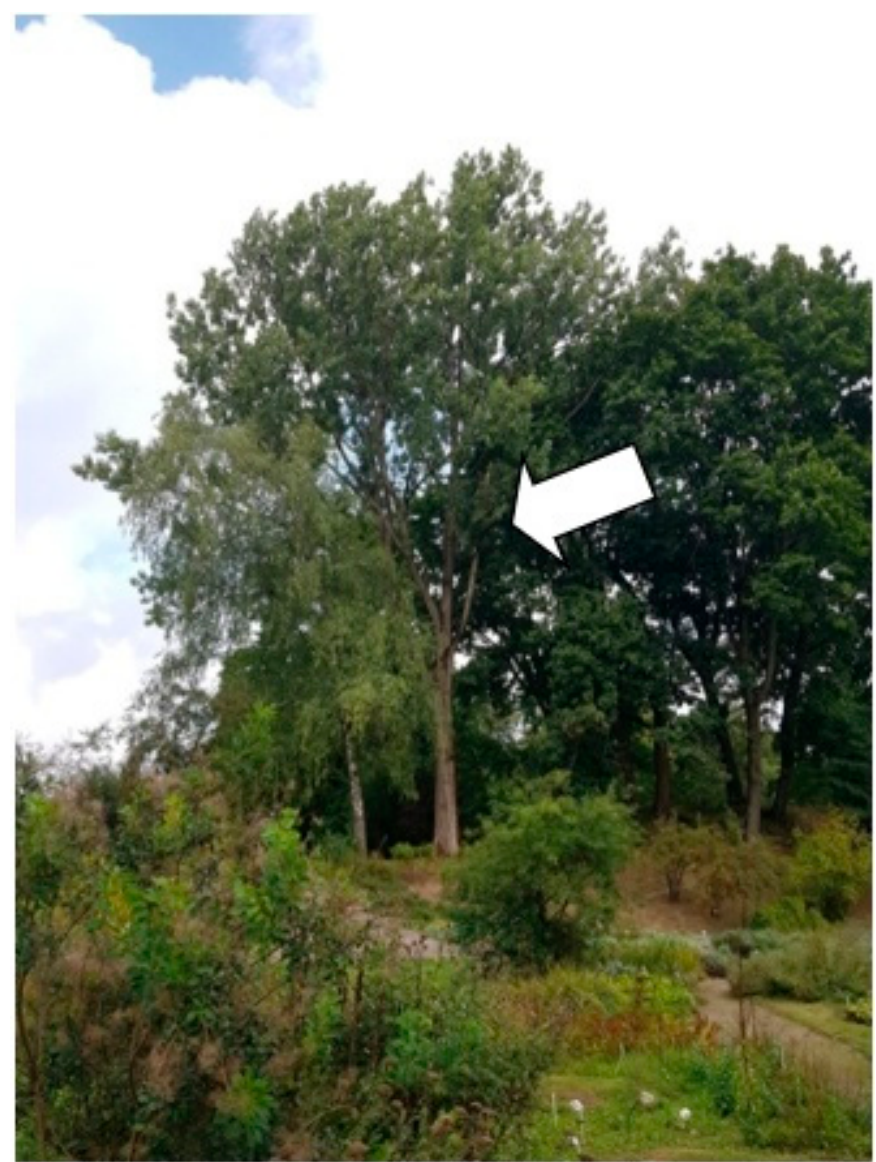

Figure 16. Canadian Poplar inv. No. 5 (photo by M. Dudkiewicz).

\subsection{Characteristics of Threats to Monumental Trees}

As already mentioned, the area of the present Botanical Garden occupies the area of the former manor complex. The trees grow here on an area of 20 ha, in very good habitat conditions. The health status of the five selected specimens was primarily influenced by 
the passage of time (Table 2). Currently, these trees are about 120 years old. The five trees selected for the study are in a disturbing condition, e.g., deadwood. However, CT examinations in only three trees confirmed disturbing changes in the internal trunk. Two more trees only require maintenance pruning.

Table 2. Results of dendrological expertise and factors damaging monumental trees (by authors).

\begin{tabular}{ccccc}
\hline No. & Species Name & Damaged Wood & Recommendation & Causes of Destruction \\
\hline 1 & $\begin{array}{c}\text { Small-leaved lime } \\
(\text { Tiliacordata Mill. })\end{array}$ & $34 \%$ & monitoring twice a year & age \\
\hline 2 & $\begin{array}{c}\text { Small-leaved lime } \\
(\text { Tiliacordata Mill. })\end{array}$ & $85 \%$ & monitoring twice a year \\
leaving as a veteran tree & monitoring twice a year \\
\hline 3 & $\begin{array}{c}\text { Norway maple } \\
(\text { Acer platanoides L. })\end{array}$ & $39 \%$ & monitoring once a year & tree in good condition \\
\hline 5 & $\begin{array}{c}\text { Norway maple } \\
\text { (Acer platanoides L. })\end{array}$ & $0 \%$ & monitoring once a year & tree in good condition \\
\hline Canadian Poplar & & $1 \%$ & &
\end{tabular}

\section{Discussion-Tomograph as a Tool Supporting the Management of Historical Greenery}

The safety of Redoubt users is crucial and requires the use of precise diagnostic techniques to detect structural changes inside tree trunks. Visual tree assessment (VTA) is still the starting point for such studies [31-33]. However, internal defects of tree trunks often remain invisible to the naked eye [34]. For many years, the only available instrument for a detailed assessment of the inner wood structure of a growing tree was the Pressler drill. However, this method requires intervention in the internal tissues of the tree. Its use in the case of precious historic trees is controversial [35]. The most appropriate methods are those that minimize the destructive impact of research methods on a tree, such as acoustic tomography with the use of Picus tools. Compared to other methods, sonic tomography is very effective, even in the early stages of wood decomposition [36].

Many research teams have confirmed the effectiveness of sonic tomography in detecting tree decay [37-46]. At the beginning of the 21st century, research was conducted on the health condition of urban trees using various research methods (electrical and sonic tomography and GPR), achieving various degrees of success in them. Among the methods used, sonic tomography turned out to be the most effective tool for detecting internal tissue decomposition, which, according to the authors, is the most accurate in locating anomalies and estimating their dimensions and shapes. Gilbert and Smiley (2004) [37], who also assessed the effectiveness of this method, stated that the average accuracy of the device is $89 \%$. Rapid prevention of degradation of the protected specimen and arboricultural work to maintain the tree in a proper condition (e.g., proper pruning, lowering the crown) contributes to preserving the rich biodiversity of the botanical garden. The studies of subsequent teams of scientists concern the impact of the number of sensors on the accuracy of measurement, the use of a device to assess the health condition of tree trunks of unusual sizes, or the assessment of the time needed for measurement and proposing an optimal workflow. The authors of this study conducted research on the use of Picus Sonic 3 in the process of revalorization of the surroundings of historic churches, as well as roadside alleys and palace and park complexes. The need for such research results from the demand of the Polish community of conservators and architects for new methods and tools supporting the shaping of space. The research confirmed the legitimacy of the use of the selected method and the correct selection of tools appropriate for the study of cultural heritage and regional architecture. The collected data constituted an information base on the resources of the stand and served as the basis for the development of projects for the revalorization of objects [47-52]. This was the first time that a similar study was used in a botanical garden. 


\section{Conclusions}

Based on the above research, it was possible to confirm the preliminary assumption that sound tomography can be a critical element in the sustainable management of historical greenery in botanical gardens. Historic trees contribute to the preservation of the natural, cultural, and biodiversity of the Garden. They are a habitat for many insects, birds, small mammals, bees, and wild bees. The applied method of tree health condition assessment using sonic tomography is an innovative research technique enabling non-invasive analysis of the internal tree trunk structures. Visual assessment is still the basis for such tests; however, internal defects in tree trunks often do not give visible external symptoms. The non-invasive detection of wood damage inside the trunk using the Picus Sonic 3 tomograph is entirely safe for the examined tree. Thanks to tomography, trees classified as potentially threatening to safety are designated for observation or nursing treatments correcting their statics, removing potential threats, or strengthening branches and branches with various types of bonds. The correction of the tree conformation is achieved by skillful cuts that reduce the crown's weight or mechanical reinforcements and supports. However, it does not remove the cause of the hazard but protects the tree against falling for some time. The results of the diagnoses are presented on an ongoing basis, which means that we can assess the condition of the tree in the field. A significant advantage is also obtaining a visualization of the entire cross-section of the trunk. An additional advantage is the ability to calculate, among others, the coefficient determining the mechanical strength of the trunk $(t / R)$, i.e., the ratio of healthy wood $(t)$ to the radius of the tree trunk $(R)$ and the geometric moment of inertia, which then allows one to estimate the strength of the trunk fracture, and the GPS location, which is automatically saved in the device.

The Lublin Botanical Garden conducts research in the field of plant ecology and physiology. Activities are focused on the problems of biodiversity protection in the plant world. In the Botanical Garden, methods of reproduction and preservation of various species of endangered and dying plants in the Lublin region are being developed. The next group of activities is directly related to the management of the existing greenery of the Botanical Garden. Inventory and tomograph examinations made it possible to select trees for care and conservation works in the Reduta area. All actions taken in the matter of the park should be based on the Environment Protection Act dated 27 April 2001 [53], which-according to Art. 3 points 5015-is understood as socio-economic development in which the process of integrating political, economic, and social activities takes place, while maintaining the natural balance and durability of basic natural processes, in order to guarantee the possibility of satisfying the basic needs of individual communities or citizens of both the modern generation and future generations. Thus, this research made it possible to assess the health condition of trees and to promote the park, which was enriched with a facility under the protection of the Provincial Conservator of Monuments. Reduta has become a new tourist attraction of the city.

Based on the research results on trees, maintenance works were carried out, and the Redoubt was entered into the Lublin register of monuments. Thanks to its high aesthetic values, the object is an attractive and safe area for sightseeing and recreation.

Author Contributions: Conceptualization, M.D. and W.D.; methodology, M.D. and W.D.; software W.D.; formal analysis, M.D. and W.D.; investigation, M.D. and W.D.; data curation, M.D. and W.D.; writing-original draft preparation M.D. and W.D.; writing—review and editing, M.D. and W.D.; visualization, M.D. and W.D.; supervision, M.D and W.D. Both authors have read and agreed to the published version of the manuscript.

Funding: This research received no external funding.

Institutional Review Board Statement: Not applicable.

Informed Consent Statement: Not applicable.

Data Availability Statement: Not applicable. 
Acknowledgments: The research was financed from the own funds of the Department of Landscape Architecture and the Institute of Horticultural Production.

Conflicts of Interest: The authors declare no conflict of interest.

\section{References}

1. Goddard, M.; Dougill, A.; Benton, T. Scaling Up from Gardens: Biodiversity Conservation in Urban environments. Trends Ecol. Evol. 2010, 25, 90-98. Available online: https://www.sciencedirect.com/science/article/abs/pii/S0169534709002468 (accessed on 29 May 2021). [CrossRef]

2. Kaneko, N.; Yoshiura, S.; Kobayashi, M. Sustainable Living with Environmental Risks; Springer Science \& Business Media: Tokyo Japan, 2014.

3. Beninde, J.; Veith, M.; Hochkirch, A. Biodiversity in Cities Needs Space: A Meta- Analysis of Factors Determining Intra-Urban Biodiversity Variation. Ecol. Lett. 2015, 18, 581-592. Available online: https:/ / onlinelibrary.wiley.com/doi/epdf/10.1111/ele.12 427 (accessed on 29 May 2021). [CrossRef]

4. Aronson, M.; Lepczyk, C.; Evans, K.; Goddard, M.; Lerman, S.; MacIvor, S.; Nilon, C.; Vargo, T. Biodiversity in the City: Key Challenges for Urban Green Space Management. Front. Ecol. Environ. 2017, 15, 189-196. Available online: https://esajournals. onlinelibrary.wiley.com/doi/10.1002/fee.1480 (accessed on 29 May 2021). [CrossRef]

5. Dudkiewicz, M. Application of Picus Sonic Tomograph 3 in Studies on the Cultural Heritage of the Lublin Region-Restoration of the EASTERN Orthodox Church of the Dormition of the Blessed Virgin Mary in Uhrusk. Annals of Warsaw University of Life Sciences. Hortic. Landsc. Archit. 2019, 40, 3-14. Available online: http://annals-wuls.sggw.pl/?q=node/1070 (accessed on 29 May 2021).

6. Chiesura, A. The Role of Urban Parks for the Sustainable city. Landsc. Urban Plan. 2004, 68, 129-138. Available online: https:/ / www.sciencedirect.com/science/article/abs/pii/S0169204603001865 (accessed on 29 May 2021). [CrossRef]

7. Karlinasari, L.; Lestarni, A.T.; Nanabar, M.Y.S.; Siregar, I.Z. Assessment of Urban tree Condition Using Sonic Tomography Technology. IOP Conf. Ser. Earth Environ. Sci. 2018, 203, 012030. Available online: https://iopscience.iop.org/article/10.1088/17 55-1315/203/1/012030 (accessed on 29 May 2021). [CrossRef]

8. A Guide to Identifying, Assessing, and Managing Hazard Trees in Developed Recreational Sites of the Northern Rocky Mountains and the Intermountain West 2017; United States Department of Agriculture: Washington, DC, USA, 2017.

9. Łakomy, K. Site-Specific Determinants and Remains of Medieval City Fortifications as the Potential for Creating Urban Greenery Systems Based on the Example of Historical Towns of the Opole Voivodeship. Sustainability 2021, 13, 7032. Available online: https:/ / www.mdpi.com/2071-1050/13/13/7032 (accessed on 29 May 2021). [CrossRef]

10. Konijnendijk, C.; Nilsson, K.; Randrup, T.B.; Schipperijn, J. Urban Forests and Trees; Springer: Berlin/Heidelberg, Germany, 2015.

11. Vidal, D.; Pitarma, R. Infrared thermography applied to tree health assessment: A review. Agriculture 2019, 9, 156. [CrossRef]

12. Ostrovsky, R.; Kobza, M.; Gazo, J. Extensively damaged trees tested with acoustic tomography considering tree stability in urban greenery. Trees 2017, 31, 1015-1102. [CrossRef]

13. Allison, R.B.; Wang, X.; Senalik, C.A. Methods for Nondestructive Testing of Urban Trees. Forests 2020, 11, 1341. [CrossRef]

14. Naumiuk, H. The History of Sławinek and the Beginnings of the UMCS Botanical Garden 2016. Available online: http: / / www.domkulturylsm.pl/?p=9873access21-05-29 (accessed on 29 May 2021).

15. Kościuszko Manor House in Sławinek. Available online: https://www.umcs.pl/pl/historia,2361.htm (accessed on 29 May 2021).

16. Fiuta, Ł. The Kościuszko Manor House in Lublin, in: Lexicon of Lublin. 2020. Available online: http://teatrnn.pl/leksykon/ node/3247/dworek_ko\%C5\%9Bciuszk\%C3\%B3w_w_lublinie (accessed on 29 May 2021).

17. Kseniak, M. The forgotten redoubt of General Tadeusz Kościuszko in the UMCS Botanical Garden in Sławinek in Lublin. Lub. Libr. 2019, LXVII, 95-110. Available online: http:/ / cejsh.icm.edu.pl/cejsh/element/bwmeta1.element.desklight-879f0cfd-7d5b-4caa9f22-962ff887a84b (accessed on 29 May 2021).

18. Kseniak, M. The forgotten redoubt of General Tadeusz Kościuszko in the UMCS Botanical Garden in Sławinek in Lublin. Conserv. News Prov. Lub. 2019, LXII, 181-192.

19. Woycicki, K.; Sobieszczański, F.M.; Kraszewski, J.I.; Pankiewicz, J.; Rogalski, L. The Universal Encyclopedia of S. Orgelbrand; Samuel Orgelbrand Publishing House: Warsaw, Poland, 1866; Volume 22, p. 11.

20. Meciszewski, F.N. Field Fortification; Drukarnia Glucksberga: Warsaw, Poland, 1825; p. 2.

21. History of the Districts-Sławin and Sławinek. Print: Ad Astra 69. 2017. Available online: https://lublin.eu/gfx/lublin/ userfiles/_public/kultura/do_pobrania/slawin_i_slawinek.pdfaccess21-05-29 (accessed on 29 May 2021).

22. Majdecki, L. Age Table of Trees; Landscape Architecture Department of Warsaw University of Life Sciences: Warsaw, Poland, 1980-1986.

23. Gocke, L.; Rust, S.; Weihs, U.; Ginther, T.; Riicker, C. Combining Sonic and Electrical Impedance Tomography for the Nondestructive Testing of Trees. In Proceedings of the 15th International Symposium on Nondestructive Testing of Wood, Duluth, MN, USA, 10-12 September 2007; pp. 31-42.

24. Brazee, N.J.; Marra, R.; Gocke, L.; Van Wassenaer, P. Non-Destructive Assessment of Interna! Decay in Three Hardwood Species of Northeastern North America Rusing Sonic and Electrical Impedance Tomography. Forestry 2011, 84, 33-39. Available online: https:/ / www.researchgate.net/publication/327778264_Estimating_carbon_loss_due_to_internal_decay_in_living_trees_ using_tomography_Implications_for_forest_carbon_budgets (accessed on 29 May 2021). [CrossRef] 
25. Chomicz, E. Non-Invasive Methods of Detecting Defects Inside the Trunks of Standing trees (Picus Sonic and Picus Treetronic Tomograph). For. Res. Works 2007, 3, 117-121. Available online: http://agro.icm.edu.pl/agro/element/bwmeta1.element.agroarticle-aae4d45a-3520-4dac-a697-7eb014435990 (accessed on 29 May 2021).

26. Chomicz, E. Non-Invasive Diagnosis of the Condition of Historic Trees with the Use of Picus Tomographs. Conserv. Cour. 2010, 8, 29-32. Available online: https:/ / www.nid.pl/upload/iblock/7f6/7f6ac9e8b82416efa9be341f0b30531e.pdf (accessed on 29 May 2021).

27. Kane, B.; Ryan, D.; Bloniarz, D.V. Comparing Formula that Assess Strength Lossdue to Decay in Trees. J. Arboric. 2001, $27,78-87$. Available online: https://www.researchgate.net/publication/242619669_Comparing_formulae_that_assess_strength_loss_due_ to_decay_in_trees (accessed on 29 May 2021).

28. Hayes, E. Tree Risk Assessment \& Tree Mechanics. Arborist News 2002, 6, 33-39.

29. Mattheck, C.; Bethge, K.; Weber, K. The Body Language of Trees. Encyclopedia of Visual Tree Assessment; Karlsruhe Institute of Technology-Campus North: Eggenstein-Leopoldshafen, Germany, 2015.

30. Suchocka, M. Advantages and Limitations of Using the Visual tree Assessment Method (VTA) as a Response to the Problems Related to the Threats Posed by Urban Trees. Man Environ. 2012, 36, 97-110. Available online: http://agro.icm.edu.pl/agro/ element/bwmeta1.element.agro-8494be50-ddea-4d2e-9cf6-76a3dd219a81 (accessed on 29 May 2021).

31. Hayes, E. Evaluating Tree Defects, 2nd ed.; Safetrees: Rochester, MN, USA, 2001.

32. Pokorny, J. Urban Tree Risks Management: A Community Guide to Program Design and Implementation; NA-TP-03-03; USDA Forest Service, Northeastern Area, State and Private Forestry: St. Paul, MN, USA, 2003.

33. Luley, C.L. Wood Decay Fungi Common to Living Urban Trees in the Northeast and Central United States; Urban Forestry LLC: Naples, NY, USA, 2005.

34. Wang, X.; Allison, R.B. Decay Detection in Red Oak Trees Using a Combination of Visual Inspection, Acoustic Testing, and Resistance Microdrilling. Arboric. Urban For. 2008, 34, 1-4. Available online: https://www.fs.usda.gov/treesearch/pubs/32704 (accessed on 29 May 2021).

35. Siewniak, M. Tree Care-Today. Conserv. Cour. 2010, 8, 24-28. Available online: https://bazhum.muzhp.pl/media/files/Kurier_ Konserwatorski/Kurier_Konserwatorski-r2010-t-n8/Kurier_Konserwatorski-r2010-t-n8-s24-28/Kurier_Konserwatorski-r201 0-t-n8-s24-28.pdf (accessed on 29 May 2021).

36. Nicolotti, G.; Socco, L.V.; Martinis, R.; Godio, A.; Sambuelli, L. Application and Comparison of Three Tomographic Techniques for Detection of Decay in Trees. J. Arboric. 2003, 29, 66-77. Available online: https://www.proquest.com/docview/220339099 (accessed on 29 May 2021).

37. Gilbert, E.A.; Smiley, E.T. Picus Sonic Tomography for the Quantification of Decay in White Oak (Quercus alba) and Hickory (Carya spp.). J. Arboric. 2004, 30, 277-281. Available online: https://www.researchgate.net/publication/238752354_Picus_ Sonic_tomography_for_the_quantification_of_decay_in_white_oak_Quercus_Alba_and_Hickory_Carya_spp (accessed on 29 May 2021).

38. Rabe, C.; Ferner, D.; Fink, S.; Schwarze, F. Detection of Decay in Trees with Stress Waves and interpretation of Acoustic Tomograms. Int. J. Urban For. 2004, 28, 3-19. Available online: https://www.tandfonline.com/doi/abs/10.1080/03071375.2004.9747399 (accessed on 29 May 2021). [CrossRef]

39. Deflorio, G.; Fink, S.; Schwarze, F. Detection of Incipient Decay in Tree Stems with Sonic Tomography after Wounding and Fungal Inoculation. Wood Sci. Technol. 2008, 42, 117-132. Available online: https://link.springer.com/article/10.1007/s00226-007-0159-0 (accessed on 29 May 2021). [CrossRef]

40. Li, G.; Wang, X.; Feng, H.; Wiedenbeck, J.; Ross, R.J. Analysis of Wave Velocity Patterns in Black Cherry Trees and Its Effect on Internal Decay Detection. Comput. Electron. Agric. 2014, 104, 32-39. Available online: https://www.sciencedirect.com/science/ article/abs/pii/S0168169914000684 (accessed on 29 May 2021). [CrossRef]

41. Espinosa, L.; Arciniegas, A.; Cortes, Y. Automatic Segmentation of Acoustic Tomography Images for the Measurement of Wood Decay. Wood Sci. Technol. 2017, 51, 69-84. Available online: https://www.researchgate.net/publication/310778319_Automatic_ segmentation_of_acoustic_tomography_images_for_the_measurement_of_wood_decay (accessed on 29 May 2021). [CrossRef]

42. Pereira, L.F.A.; Janssens, E.; Cavalcanti, G.D.C.; Ren, T.I.; Dael, M.V.; Verboven, P.; Nicola, B.; Sijbers, J. Inline Discrete Tomography System: Application to Agricultural Product Inspection. Comput. Electron. Agric. 2017, 138, 117-126. Available online: https: / / www.sciencedirect.com/science/article/abs/pii/S0168169916301909 (accessed on 29 May 2021). [CrossRef]

43. Liu, L.; Li, G. Acoustic Tomography Based on Hybrid Wave Propagation Model for Tree Decay Detection. Comput. Electron. Agric. 2018, 151, 276-285. Available online: https:/ / www.cabdirect.org/cabdirect/abstract/20183260102 (accessed on 29 May 2021). [CrossRef]

44. Qiu, Q.; Qin, R.; Lam, J.; Tang, A.; Leung, M.; Lau, D. An Innovative Tomographic Technique Integrated with AcousticLaser Approach for Detecting Defects in Tree Trunk. Comput. Electron. Agric. 2019, 156, 129-137. Available online: https: //www.sciencedirect.com/science/article/abs/pii/S0168169918303880 (accessed on 29 May 2021). [CrossRef]

45. Kersten, W.; Schwarze, F. Development of Decay in the Sapwood of Trees Wounded by the Use of Decay-Detecting Devices. Arboric. J. 2004, 28, 165-181. Available online: https:/ /www.researchgate.net/publication/237724152_Development_of_decay_ in_the_sapwood_of_trees_wounded_by_the_use_of_decay-detecting_devices (accessed on 29 May 2021). [CrossRef]

46. Baláš, M.; Gallo, J.; Kuneš, I. Work Sampling and Work Process Optimization in Sonic and Electrical Resistance Tree Tomography. J. For. Sci. 2020, 66, 9-21. Available online: https://www.agriculturejournals.cz/web/jfs.htm?type=article\&id=66_2019-JFS (accessed on 29 May 2021). [CrossRef] 
47. Żuraw, B.; Durlak, W.; Dudkiewicz, M.; Nowak, D. Assessment of the Health of Monumental Trees Growing in a Historic Park in Zwierzyniec Using an Acoustic Tomography. Tech. J. Sect. Archit. 2016, 1-A, 217-236. Available online: https: / / repozytorium.biblos.pk.edu.pl/resources / 29145 (accessed on 29 May 2021).

48. Durlak, W.; Dudkiewicz, M.; Szmagara, M.; Żuraw, B. Application of Picus Sonic Tomograph 3 in studies of Dendroflora-Castle and Manor Complex in Krupem, gm. Krasnystaw. Ann. Hortic. 2017, 4, 19-32. Available online: https://czasopisma.up.lublin.pl/ index.php/ah/article/view/212 (accessed on 29 May 2021).

49. Durlak, W.; Dudkiewicz, M.; Pudelska, K.; Dabski, M. Diagnosing the condition of trees with the use of computed tomography. Acta Sci. Pol. Form. Circumiectus 2017, 2, 71-83. Available online: http://www.formatiocircumiectus.actapol.net/pub/16_2_71.pdf (accessed on 29 May 2021). [CrossRef]

50. Durlak, W.; Dudkiewicz, M.; Pudelska, K.; Dabski, M. Using Picus ${ }^{\circledR}$ Sonic Tomograph to Assess the Health State of Trees of Monumental Sizes. In File of the Commission for Architecture, Town Planning and Landscape Studies of the Polish Academy of Sciences; Politechnika Lubelska: Lublin, Poland, 2017; Volume 13, pp. 73-82. Available online: https://ph.pollub.pl/index.php/teka/ article/view/1704 (accessed on 29 May 2021).

51. Dudkiewicz, M. The Use of Computed Tomography in the Revalorization of the Area around the Church of Holy Trinity in Dubienka. Landsc. Ecol. Probl. 2018, XLVII, 51-62. Available online: https:/ /www.researchgate.net/profile/Margot-Dudkiewicz (accessed on 29 May 2021).

52. Dudkiewicz, M. Application of Sound Tomography in the Revitalization of the Area Surrounding the Nativity of the Blessed Virgin Mary Orthodox Church in Włodawa. Geomat. Landmanag. Landsc. 2018, 3, 7-22. Available online: https://gll.urk.edu.pl/ zasoby/74/GLL-3-6-2018.pdf (accessed on 29 May 2021). [CrossRef]

53. Environment Protection Act Dated 27 April 2001. Available online: https://isap.sejm.gov.pl/isap.nsf/download.xsp/WDU20010 620627/U/D20010627Lj.pdf (accessed on 29 May 2021). 